\title{
Learning Objects and Their Implications on Learning: A Case of Developing the Foundation for a New Knowledge Infrastructure
}

\author{
Peter Bednar \\ University of Portsmouth, UK \\ and Lund University, Sweden
}

\author{
Christine Welch \\ University of Portsmouth, UK
}

a.graziano@shu.ac.uk

christine.welch@port.ac.uk

Almerindo Graziano

Sheffield Hallam University, Sheffield, UK

and Università di Napoli Federico II, Italy

\begin{abstract} to make responsible judgments. to accommodate support of symmetrical dialogue. needed which is capable of supporting both types of learning practice.

Material published as part of these proceedings, either on-line or in print, is copyrighted by Informing Science. Permission to make digital or paper copy of part or all of these works for personal or classroom use is granted without fee provided that the copies are not made or distributed for profit or commercial advantage AND that copies 1) bear this notice in full and 2) give the full citation on the first page. It is permissible to abstract these works so long as credit is given. To copy in all other cases or to republish or to post on a server or to redistribute to lists requires specific permission from the publisher at Publisher@InformingScience.org
\end{abstract}

In an era of lifelong learning, empowerment of the learner becomes fundamental. Therefore exploitation of the full potential of learning objects depends upon creation of an appropriate infrastructure to promote symmetrical control of inquiry. The learner needs to be empowered because learning is a discovery process and thus must be under his or her own control.

In early stages of education it is often assumed that choice of material is to be decided by experts. At the more advanced stages, however, any subject problem space becomes more complex, and thus any decision related to relevance of inquiry properly rests with the learner. However without access to relevant contextual material (in addition to content) the learner will not be in a position

Two problems are to be adduced. First, current attempts to contextualise content, such as those based on the use of Metadata etc, have been shown to be insufficient. Secondly, current developments in infrastructure assume that access and control of inquiry rests with the provider and fail

Many strategies for the use of Learning Objects assume that a learner wishes to be led through the material and precludes the possibility of an educational experience which promotes critical thinking (such as that inspired by Socratic method). We would argue that an infrastructure is

It could be argued that thinking cannot be taught and that the only thing we can hope to achieve in education is mentoring and guidance within a problem space. A number of substantial research projects have been conducted in partnership between a range of significant European industrial actors and academic institutions in recent years. Drawing upon the findings of these projects we will suggest a model for developing an infrastructure incorporating the possibility for symmetrical control of inquiry between learner and 


\section{Learning Objects and Their Implications on Learning}

provider of learning objects.

Note: The European Research Projects are as follows: EASEL - Educator Access to Services in the Electronic Landscape, a 2 year project, which focuses on authoring issues of learning material, and on metadata of such resources. GUARDIANS - Gateway for User Access to Remote Distributed Information and Network Services, a 2 year project that focuses on retrieving and validating advanced technologies for information management. EASEL: 2000 - 2001, GUARDIANS: 2001- 2003. Both EU funded 5th Framework Programmes. 